\title{
Study of Socio-Demographic and Perinatal Factors Associated with Attention Deficit Hyperactivity Disorder in Children
}

\author{
Dr. Asharul Hossain ${ }^{1 *}$, Dr. Sufia Yasmin ${ }^{2}$, Dr. Saswati Nath ${ }^{3}$
}

\author{
${ }^{1}$ Senior Resident Berhampore Mental Hospital \\ ${ }^{2}$ Medical Officer, R N Tagore UPHC \\ ${ }^{3}$ Associate Professor, R G Kar Medical College
}

DOI: $10.36347 /$ sasjm.2020.v06i11.001

| Received: 21.10.2020 | Accepted: 30.10.2020 | Published: 09.11.2020

*Corresponding author: Dr. Asharul Hossain

Abstract

Original Research Article

Attention-deficit/hyperactivity disorder (ADHD) is one of the most common Neurodevelopmental disorders in childhood and adolescence affects. Prevalence of ADHD among school-age children in different studies varies between $5 \%$ and $12 \%$ and declines with increasing age. ADHD is generally accepted as having a genetic basis but environmental influences have also been reported as contributing factors. Possible environmental risk factors reported for ADHD have included perinatal complications, these include maternal abuse of substances, prenatal and postnatal viral infections, prematurity, low birth weight, head injury during childhood and several socio-demographic factors such as maternal education, family income, gender, maternal age at pregnancy and emotional stress during pregnancy. Keywords: Socio-Demographic, Perinatal Factors Perinatal Factors

Copyright $\odot 2020$ The Author(s): This is an open-access article distributed under the terms of the Creative Commons Attribution 4.0 International License (CC BY-NC 4.0) which permits unrestricted use, distribution, and reproduction in any medium for non-commercial use provided the original author and source are credited.

\section{INTRODUCTION}

To assess the antenatal factors, birth complications, post-natal factors associated with ADHD we have done this study on children attending child guidance clinic will be screened by using Child Symptom Inventory (CSI). Children screened out as having hyper-activity finally was diagnosed as ADHD and other comorbidities according to DSM 5. Control was selected from siblings of the ADHD cases detailed history about socio-demographic and perinatal factors was taken cases and control group from parents. Our study revealed that Males were more affected than females (5:1). ADHD patients had higher birth order than their unaffected siblings. The children with ADHD had significantly higher rates of neonatal complications compared with their unaffected siblings. These results suggest that neonatal complications are probably a nonshared environmental risk factor that may be pathogenic in children with ADHD.

\section{AIMS \& OBJECTIVES}

I. To assess the socio-demography factors associated with attention deficit hyperactivity disorder in children

II. To assess the antenatal factors, birth complications, post-natal factors associated with attention deficit hyperactivity disorder in children

\section{MATERIALS AND METHODS Study setting}

The study was conducted at Child guidance clinic of the Department of Psychiatry, R G Kar Medical College, Kolkata, and West Bengal, India.

\section{Study Population}

All children, attended the child guidance clinic from august 2017 to January'2018, were enrolled in the study. All diagnosed cases of ADHD as per DSM 5 were included in the study following inclusion and exclusion criteria. Control was selected from siblings of the ADHD cases detailed history about sociodemographic and perinatal factors was taken cases and control group from parents.

\section{Study period}

After getting approval from institutional ethics committee, the work was started and continued up to January 2018. Total time period of the study were six months (August, 2017 to January, 2018).

\section{SELECTION CRITERIA \\ Inclusion Criteria}

I. Children aged from 3 years to 12 years

II. Children diagnosed with ADHD according to DSM 5 and having unaffected sibling. 


\section{Exclusion Criteria}

I. IQ bellow 70

II. Children having any obvious neurological disorder (Cerebral palsy, epilepsy, brain tumour) Children having severe perceptual problem (hearing problem, visual problem)

\section{Sample size}

It had been found that, in the child guidance clinic of R. G Kar Medical College about 2 new cases and 4 old cases of ADHD attended for the treatment in one month. That's why in our study we expected 36 patients in 6 months. Total cases were 30 and control was 30 .

\section{Methods of data collection}

Children attending child guidance clinic were screened by using Child Symptom Inventory (CSI). Children screened out as having hyper-activity finally were diagnosed as ADHD and other comorbidities according to DSM 5. Detailed history about sociodemographic and perinatal factors was taken and were noted in a semi-structured case history pro-forma and were transcribed onto a Excel database and descriptive statistics were done by using SPSS version 23 .

\section{Study design}

This is a cross sectional, descriptive, casecontrol study.

\section{Tools used in the study}

I. Child Symptom Inventory (CSI).

II. DSM 5 .

III. semi-structured case history pro-forma

\section{Statistical Analysis}

After collection of data results were analysed by using SPSS version 23 .

\section{Ethical consideration}

The study proposal along with other relevant documents was submitted to the institutional ethical committee for review and approval. The study was commenced only after the approval was obtained in writing.

\section{RESULT AND ANALYSIS}

Children with ADHD who had unaffected siblings ( $n=30$ pairs) were significantly younger than their unaffected siblings (mean age 7.40 [standard deviation \{SD 1.868 ] yrs. v. 9.30 [SD 2.037] yrs., respectively, $p=0.000$ ) (Table 1 ). Birth order was higher in the ADHD group compared with the sibling group (median 2 v. 1 respectively, $p=0.000$ ). As expected, boys were overrepresented in our study group and boys were more affected than girls. Male: female ratio was 5:1(for ADHD) and 7:23 for control) For children with ADHD and siblings, mean birth weight were respectively 2.280 [SD 0.479$] \mathrm{kgs}$ and 2.803 [SD $0.372] \mathrm{kgs}$.

Table-1: Demographic variables of study population.

\begin{tabular}{|l|l|l|l|}
\hline Variables & $\begin{array}{l}\text { ADHD } \\
\text { Mean (std. dev.) }\end{array}$ & $\begin{array}{l}\text { CONTROL } \\
\text { Mean (std. dev.) }\end{array}$ & P-VALUE \\
\hline AGE & $7.40(1.868)$ & $9.30(2.037$ & 0.000 \\
\hline BIRTH ORDER & $2.23(0.858)$ & $1.2(0.407)$ & 0.000 \\
\hline BIRTH WEIGHT & $2.280(0.479)$ & $2.803(0.372)$ & 0.000 \\
\hline
\end{tabular}

Table-2: Mean of perinatal factors in cases and controls

\begin{tabular}{|c|c|c|c|c|c|}
\hline \multicolumn{2}{|l|}{ FACTORS } & ADHD & CONTROL & TEST & P-VALUE \\
\hline \multirow[t]{2}{*}{ Antenatal general health of mother } & Weakness & $19(73.1)$ & $7(26.9)$ & \multirow[t]{2}{*}{ Pearson chi-square } & \multirow[t]{2}{*}{0.002} \\
\hline & Good & $11(32.4)$ & $23(67.6)$ & & \\
\hline \multirow[t]{2}{*}{ Pregnancy induced hypertension } & Present & $17(85.0)$ & $3(15.0)$ & \multirow[t]{2}{*}{ Pearson chi-square } & \multirow[t]{2}{*}{0.000} \\
\hline & Absent & $13(32.5)$ & $27(67.5)$ & & \\
\hline \multirow[t]{2}{*}{ Gestational diabetes } & Present & $10(76.9)$ & $3(23.1)$ & \multirow[t]{2}{*}{ Pearson chi-square } & \multirow[t]{2}{*}{0.028} \\
\hline & Absent & $20(42.6)$ & $27(57.4)$ & & \\
\hline \multirow{2}{*}{ Antenatal haemorrhage } & Present & $15(83.3)$ & $3(16.7)$ & \multirow{2}{*}{ Pearson chi-square } & \multirow{2}{*}{0.001} \\
\hline & Absent & $15(35.7)$ & $27(64.3)$ & & \\
\hline \multirow[t]{2}{*}{ Attempted abortion } & Present & $4(100.0)$ & $0(0.0)$ & \multirow[t]{2}{*}{ Fisher's Exact test } & \multirow[t]{2}{*}{0.112} \\
\hline & Absent & $26(46.4)$ & $53.6)$ & & \\
\hline \multirow[t]{2}{*}{ Premature rupture of membrane } & Present & $14(82.4)$ & $3(17.6)$ & \multirow[t]{2}{*}{ Pearson chi-square } & \multirow[t]{2}{*}{0.002} \\
\hline & Absent & $16(37.2)$ & $27(62.8)$ & & \\
\hline \multirow[t]{2}{*}{ IUGR } & Present & $23(85.2$ & $4(14.8)$ & \multirow[t]{2}{*}{ Pearson chi-square } & \multirow[t]{2}{*}{0.000} \\
\hline & Absent & $7(21.2)$ & $26(78.8)$ & & \\
\hline \multirow[t]{2}{*}{ Maturity } & Preterm & $14(82.4)$ & $3(17.6)$ & \multirow[t]{2}{*}{ Fisher's exact test } & \multirow[t]{2}{*}{0.005} \\
\hline & Term & $16(34.04)$ & $31(65.95$ & & \\
\hline \multirow[t]{2}{*}{ Delayed birth cry } & Present & $16(80.0)$ & $4(20.0)$ & \multirow[t]{2}{*}{ Pearson chi-square } & \multirow[t]{2}{*}{0.001} \\
\hline & Absent & $14(35.0)$ & $26(65.0)$ & & \\
\hline \multirow[t]{3}{*}{ Septicaemia } & Present & $9(81.8)$ & $2(18.2)$ & \multirow[t]{3}{*}{ Pearson chi-square } & \multirow[t]{3}{*}{0.020} \\
\hline & Absent & $21(42.9)$ & $28(57.1)$ & & \\
\hline & Absent & & & & \\
\hline
\end{tabular}


Table 2 showing that in our study the ADHD patients and their siblings were different in many aspects. Their antenatal, perinatal and post natal histories were different very significantly. Patients with ADHD were having mother(73.10\%) with weakness and poor health during pregnancy compared to their siblings $(26.90 \%)$ with P-value-0.002. patients with ADHD mother having pregnancy induced hypertension $85 \%$, gestational diabetes $76.90 \%$, antenatal haemorrhage $83.30 \%$, attempted abortion $100 \%$, premature rupture of membrane $82.40 \%$, Intra-uterine growth retardation $85.20 \%$, prematurity $82.40 \%$, delayed birth cry $80.00 \%$, septicaemia $81.80 \%$ than their affected siblings $15 \%, 23.10 \%, 16.70 \%$, $00.0 \%, 17.60 \%, 14.80 \%, 17.60 \%, 20.0 \%$, and $18.20 \%$ respectively and $\mathrm{P}$-value of the distribution were 0.000 , $0.28,0.001,0.112,0.002,0.000,0.005,0.001$ and 0.020 respectively. According to our study the ADHD patients are different from their siblings in different antenatal, perinatal and post natal complications.

\section{DISCUSSION}

Perinatal complications have been the most studied of the environmental factors implicated in the pathogenesis of ADHD and have received some validity from animal studies.14 the literature indicates that many confounding factors (socioeconomic status, maternal IQ, family history) can limit the interpretation of casecontrol studies. An intrafamilial study comparing children with ADHD with their unaffected siblings may provide excellent-to-good matching between cases and controls for several environmental factors and, to a certain extent, for the genetic background. Genetic epidemiologic studies identify mainly nonshared environmental factors, whereas case- control studies identify factors that are more likely to be common to all children in the same family, such as maternal smoking and alcohol consumption, both of which may share genetic determinants with ADHD. Thus, using intrafamilial case-control studies may help to clarify the complexity of the interaction between genetic and environmental factors that may be implicated in this disorder The first main finding of this study is that the profile of antenatal, perinatal and post natal complications during developmental periods in children with ADHD and their unaffected siblings was not parallel. This is mainly because of an increased level of neonatal complications in the children with ADHD. In contrast to pregnancy, labour and delivery, events experienced in the neonatal period, when the child is more independent of the mother, are conceivably more likely to be specific to each individual, that is, a nonshared factor. This result may suggest that neonatal complications may be a risk factor with a putative causal link to the development of ADHD. This result is also consistent with the fact that genetic epidemiologic studies have identified mainly nonshared environmental factors in ADHD. In our study ADHD patients are having more low birth weight than their sieblings. Surprisingly, in the literature, low birth weight (LBW)
$(<2500 \mathrm{~g})$ as a neonatal risk factor was almost exclusively associated with ADHD.35-38 in these studies, ADHD was a frequent outcome for LBW children; however, LBW children also experienced greater developmental delay. This association may be the result of the effects of general developmental problems. Moreover, other studies12, 39, 40 have reported that LBW was associated only with lower IQ scores but not with ADHD. The effect of LBW on attention and motor behaviour remains controversial.13 Apart from LBW, no other abnormal neonatal conditions have been reported to be associated with ADHD. The effect of LBW on attention and motor behaviour remains controversial.13 Apart from LBW, no other abnormal neonatal conditions have been reported to be associated with ADHD. In the study group, medical conditions that were more frequent in ADHD included several events occurring during the first 2 months of life: neonatal admission to hospital, having been in an incubator, oxygen therapy, general anaesthesia and surgery being the most frequent. Although these findings do not point to a single event that may lead to behavioural or cognitive problems, they do support past research indicating that children with ADHD have a higher prevalence of stressful events in early life.12 Moreover, these factors, consistent with previous research, suggest that prolonged chronic rather than acute stresses are more likely to be associated with ADHD. It is interesting that some of these factors are clearly associated with hypoxia (e.g., oxygen therapy). This is consistent with findings from animal models indicating that neonatal hypoxia can result in increased locomotors activity later in life.41-43 the relation of these neonatal events to pregnancy and labour/delivery needs to be analysed in order to assess their specific role in increasing the risk for ADHD. Surprisingly, smoking and alcohol consumption during pregnancy, which is often reported as environmental risk factors for ADHD, did not differ between patients and their unaffected relatives. Smoking was equally common $(58 \%)$ in pregnancies leading to affected and unaffected children. Remarkably, this rate is higher than the rate observed in the general population of Quebec (40\%).

Several limitations should be kept in mind when interpreting the results of this study. First, our conclusions are based on a sample of 30 children with ADHD and 30 of their unaffected siblings. This is of course a small sample for risk studies. These results need to be confirmed in a larger group in order to ensure their validity. Second, comorbidity is very high in ADHD; it would have been very informative to study perinatal complication according to comorbid disorders. However, the small sample precluded this analysis. Another limitation of this study is that boys were overrepresented in the ADHD group. However, given that girls may be more resilient to developing the disorder, it is expected that some girls may have a high level of perinatal complication and yet do not express 
the disease. This bias may therefore be conservative, that is, unlikely to result in false-positive findings. A further limitation of this study is the difference in age and birth rank. Here again, most of the affected children were younger and resulted from a second pregnancy, which is usually considered to be at lower risk than a first pregnancy. Another limitation of this design is its reliance on a maternal retrospective interview, which is the case for almost all studies of maternal lifestyle during pregnancy.17 In order to have information about the validity of the maternal report; we compared the maternal reports with the information derived from the medical files for $60 \%$ of the patients. As reported in the literature, 49 we found that mothers tended to underreport PLDNC. Finally, although using siblings as controls reduces a large number of potential biases, it does not control for $50 \%$ of the genes that differ between siblings, making this design more robust than case-control studies but less so than twin studies, which are difficult to conduct.

\section{CONCLUSIONS}

To our knowledge, there are very few studies to use an intrafamilial design to address the implication of perinatal complications in ADHD. This design has the important advantage of controlling for many confounding factors, including, to a certain extent, the genetic background. It might be a useful intermediate tool between unrelated case-control and twin risk studies. In addition, this type of design may help to delineate the nature of environmental risk factors and to understand the role of the different factors in the expression of ADHD. The results of this study suggest that neonatal complications are more frequent in children with ADHD compared with their unaffected relatives.

These results suggest that neonatal complications are probably a nonshared environmental risk factor that may be pathogenic in children with ADHD.

\section{REFERENCE}

1. Linnet KM, Dalsgaard S, Obel C, Wisborg K, Henriksen TB, Rodriguez A, Kotimaa A, Moilanen I, Thomsen PH, Olsen J, Jarvelin MR. Maternal lifestyle factors in pregnancy risk of attention deficit hyperactivity disorder and associated behaviors: review of the current evidence. American Journal of Psychiatry. 2003 Jun 1;160(6):1028-40.

2. Grizenko N, Shayan YR, Polotskaia A, Ter-Stepanian M, Joober R. Relation of maternal stress during pregnancy to symptom severity and response to treatment in children with ADHD. Journal of psychiatry \& neuroscience: JPN. 2008 Jan;33(1):10.
3. Faraone SV, Sergeant J, Gillberg C, Biederman J. The worldwide prevalence of ADHD: is it an American condition?. World psychiatry. 2003 Jun;2(2):104.

4. Biederman J, Faraone SV, Spencer T, Wilens T, Mick E, Lapey KA. Gender differences in a sample of adults with attention deficit hyperactivity disorder. Psychiatry research. 1994 Jul 1;53(1):13-29.

5. Martin N, Scourfield J, McGuffin P. Observer effects and heritability of childhood attention-deficit hyperactivity disorder symptoms. The British Journal of Psychiatry. 2002 Mar;180(3):260-5.

6. Eaves, L. J., Silberg, J. L., Meyer, J. M., Maes, H. H., Simonoff, E., Pickles, A., ... \& Neale, M. C. (1997). Genetics and developmental psychopathology: 2. The main effects of genes and environment on behavioral problems in the Virginia Twin Study of Adolescent Behavioral Development. Journal of Child Psychology and Psychiatry, 38(8), 965-980.

7. Biederman J, Milberger S, Faraone SV, Kiely K, Guite J, Mick E, Ablon S, Warburton R, Reed E. Family-environment risk factors for attention-deficit hyperactivity disorder: A test of Rutter's indicators of adversity. Archives of general psychiatry. 1995 Jun 1;52(6):464-70.

8. Banerjee TD, Middleton F, Faraone SV. Environmental risk factors for attention- deficit hyperactivity disorder. Acta paediatrica. 2007 Sep;96(9):1269-74.

9. Malhi P, Singhi P. Spectrum of attention deficit hyperactivity disorders in children among referrals to psychology services. Indian pediatrics. 2000;37(11):1256-60.

10. Tsao PC, Lee YS, Jeng MJ, Hsu JW, Huang KL, Tsai SJ, Chen MH, Soong WJ, Kou YR. Additive effect of congenital heart disease and early developmental disorders on attention-deficit/hyperactivity disorder and autism spectrum disorder: a nationwide population-based longitudinal study. European Child \& Adolescent Psychiatry. 2017 Nov 1;26(11):1351-9.

11. Böhm S, Curran EA, Kenny LC, O'Keeffe GW, Murray D, Khashan AS. The Effect of Hypertensive Disorders of Pregnancy on the Risk of ADHD in the Offspring. Journal of Attention Disorders. 2019 May;23(7):692-701.

12. Hanć $T$, Szwed A, Słopień A, Wolańczyk T, Dmitrzak-Węglarz M, Ratajczak J. Perinatal risk factors and ADHD in children and adolescents: a hierarchical structure of disorder predictors. Journal of attention disorders. $2018 \mathrm{Jul} ; 22(9): 855-63$.

13. Curran EA, Khashan AS, Dalman C, Kenny LC, Cryan JF, Dinan TG, Kearney PM. Obstetric mode of delivery and attention-deficit/hyperactivity disorder: a sibling-matched study. International journal of epidemiology. 2016 Apr 1;45(2):532-42.

14. Boksa P, El-Khodor BF. Birth insult interacts with stress at adulthood to alter dopaminergic function in animal models: possible implications for schizophrenia and other disorders. Neurosci Biobehav Rev. 2003;27(1-2):91-101. 